\title{
The Alexander Turnbull Library
}

By LODA MAE DAVIS

$\mathrm{F}^{\mathrm{o}}$ OR FIVE WEEKS I enjoyed the hospitality of the Alexander Turnbull Library in Wellington, New Zealand, while studying their collection of works on the culture of the Polynesian islands of the South Pacific. To most of us, these are Utopian isles where manna falls from heaven into the waiting mouth of the traveler and work is all play. But to the New Zealanders they are lands where people strive to provide food, to obtain a few of our conveniences, to educate their children, and to learn more about Western ways of life. It is fitting, therefore, that the best library collection of works on Polynesia should be found in that outpost of Western civilization closest to Polynesia, New Zealand.

The Turnbull collection became the property of the people of New Zealand through the bequest of Alexander Horsburgh Turnbull of his private library, in 1918. Later the Turnbull home was purchased to house the collection. It was completely remodeled four years ago. The library has the atmosphere of a treassure house where gentlemen readers might browse, yet it is a part of the public library system of New Zealand, administered by the Internal Affairs Department, and financed by government funds.

Mr. Turnbull was a man of discernment, the bachelor son of a wealthy Wellington merchant family, who even at the end of the nineteenth century appreciated the importance of the literature, and of development of New Zealand and the South Pacific. The original
Miss Davis is Dean of Women, University of California, Riverside.

collection of fifty-five thousand volumes consisted of thousands of the finest rare books and original editions of English literature, original manuscripts, letters, maps, books before 1640, current books and periodicals of his time, paintings, portraits, photographs, and book bindings. On the walls hang original paintings and in the large bookcases are found some of the best examples of the art of ancient and modern bookbinders. There are some four thousand pictures, including works of the artists and draftsmen who accompanied the first Dutch to come to this area, and a photograph collection consisting of some hundreds of thousands of negatives covering the history and development of New Zealand.

The Pacific collection includes material on New Zealand, Australia, Polynesia, Melanesia, Micronesia, Indonesia, and Malaysia. The Australian, Malaysian, and Indonesian areas are covered well but not exhaustively. The material on the Oceanic Islands, however, is gathered as fully as possible and is probably superior to any other collection of its kind. There are strong holdings on the ethnology and linguistics of the native peoples of the Pacific. On the native languages alone, of which there are some four hundred, there are over six thousand volumes. The library owns a considerable 
number of paintings by early New Zealand and Maori artists. Captain Cook's $\log$ of the Eagle in 1755-56; the journal of Gallego, master pilot on Mendana's voyage of 1563 , when he discovered the Solomon Islands; the journey of Antoneli who explored the coast of South America in 1608; the earliest printed accounts of the voyages of Magellan; and papers and letters of the Scott-Shackleton expeditions to the South Pole are stored here. In the Pacific section are the collected editions of Hakluyt 1599-1600, Linschoten 1598, De Bry 1590-1634, Thevenot 1663-96, Callender 1766-68, and the long series of the Linschoten Society and the Hakluyt Society. There are also many manuscripts on Maori history and culture.

The non-Pacific section consists of a number of collections, with the important emphasis on English, Scottish, and New Zealand literature. The constant objective of the library is to maintain homogeneity in its collections. The office of the director of the library houses one of the finest Milton collections in existence, with many first editions and hand bound volumes. Good collections also gather about the names of Samuel Butler, Kipling, the Brownings, William Morris, Defoe, Thackeray, and Shakespeare. Scottish literature is particularly full. Sets of many periodicals are found -English Literary History, the Edinburgh Review, Scots Magazine, the Review of English Studies, the Modern Language Review, publications of the Modern Language Association of America. Supporting these groups are works of biography referring to most of the writers whose works are shelved. The collection of fifteenth-century books, while not large, is choice, and there are examples of books from the presses of Stephanus, Aldus, Plantin, Elzevir, Koberger, Ratdoldt, Baskerville, down to the Ashendene, Kelmscott, Golden Cockerel, Doves, and Nonesuch. There is an extremely choice collection of about two thousand volumes on art. The history section is not large but contains some early chronicles in Scottish and Irish history, books on Canadian and West Indian history for the early period, Italian statecraft of the fifteenth and sixteenth centuries, and of World War I.

Turnbull is not a lending library, since many of its hundred thousand titles are unique, and therefore can be used only on the premises. The library will do a certain amount of research for people at a listance, however, and carries on considerable correspondence, as well as forwarding microfilmed material at a nominal charge. In so far as possible, the library participates in an interlibrary loan program, lending material that is not irreplaceable. The collection of microfilm material of the earliest records of voyages, papers of the first missionaries, and original documents housed in London, is increasing.

In its operation, the library has been influenced more by the American library pattern than by the English system. The library is related closely to the community. Technically, the Dewey Decimal system and American Library Association rules are followed. With the help of the Ford Foundation, the Turnbull Library is now receiving microfilm of English literature prior to 1640 .

The New Zealand libraries have a problem to find and keep trained personnel. Because of comparatively low salaries paid to the professional library staff and to university professors, libraries and universities have suffered. Some of the best people have been lured away by the better salaries paid in Australia and the United States.

The homelike atmosphere of the stately mansion and the courtesy and efficiency of the staff make the Turnbull Library a hospitable and comfortable environment in which to do library research. It should become more widely known, as New Zealand draws more overseas visitors. 